CLINICAL HEMORHEOLOGY, Vol. 11, p. 141, 1991

$0271-5198 / 91 \$ 3.00+.00$ Printed in the USA.

Copyright (c) 1991 Pergamon Press plc. All rights reserved.

\title{
CONTENTS OF BIORHEOLOGY, VOLUME 27, NUMBER 5
}

VOLUME 27, NUMBER 5

\author{
P. Chaturani and V. Palanisamy \\ H. Ertepinar, B. Süzen, A. Özoran, \\ Y. Özoran, S. Ceylan, G. Yeginoglu \\ and G. Üremek \\ D.R. Bell, H.N. Sabbah \\ and P.D. Stein \\ M. Safari, A. Bjelle, M. Gudmundsson, \\ C. Högfors and $\mathrm{H}$. Granhed \\ J. Ando, T. Komatsuda, C. Ishikawa \\ and A. Kamiya
}

G.B. Thurston

S. Zaiss

D.E. Mann and J.M. Tarbell

R. Grebe and M.J. Zuckerman

P. Chaturani and V. Palanisamy

R. Yamamoto and N. Sakurai

M. Long, Y. Toyama, T. Dobashi, A. Sakanishi, Y. Peng Wu and S. Oka

A.A. Stadler, E.P. Zilow and $\mathrm{O}$. Linderkamp

L.S. Lam and J.L. Bert

C.L. Lucas, B.R. Wilcox, G.W. Henry, J.I. Ferreiro and M. Singh

\section{Contents}

Papers

619 Casson fluid model for pulsatile flow of blood under periodic body acceleration

631 Effects of drag reducing polymer on atherosclerosis

645 Fatty streak development in the vicinity of aortic coarctations in hypercholesterolemic rabbits

659 Clinical assessment of rheumatic diseases using viscoelastic parameters for synovial fluid

675 Fluid shear stress enhanced DNA synthesis in cultured endothelial cells during repair of mechanical denudation

685 Light transmission through blood in oscillatory flow

701 The influence of calcium on the deformability of human granulocytes

711 Flow of non-Newtonian blood analog fluids in rigid curved and straight artery models

735 Erythrocyte shape simulation by numerical optimization

747 Pulsatile flow of power-law fluid model for blood flow under periodic body acceleration

759 A computer simulation of the creep process of the cell wall using stress relaxation parameters

769 Effect of electric field on erythrocyte sedimentation rate II. Dependence on electric current

779 Blood viscosity and optimal hematocrit in narrow tubes

Brief Communications

789 Hydraulic flow conductivity of hyaluronic acid solutions: Effects of concentration and molecular weight

797 Influence of posture variation on fluid flow patterns in a curved tube

807 Announcements 